\title{
Atletik Performans ve Spor Genetiği
}

\author{
Nurten Dinç ${ }^{1}$, Mehmet Hilmi Gökmen ${ }^{1}$ \\ ${ }^{1}$ Manisa Celal Bayar Üniversitesi, Spor Bilimleri Fakültesi, Manisa, Türkiye \\ email:nurten.dinc@hotmail.com, mehmethilmi93@gmail.com \\ Orcid:0000-0001-9365-2574 \\ Orcid: 0000-0002-3848-7569 \\ *Sorumlu Yazar / Corresponding Author: Sorumlu Yazar: Nurten Dinç ${ }^{1}$
}

Gönderim Tarihi / Received: 19.02.2019

Kabul Tarihi / Accepted: 19.03.2019

DOI: $10.34087 /$ cbusbed.529159

\begin{abstract}
Öz
Günümüzde spora amatör veya profesyonel katılım arttıkça sportif performans ve bu performansı etkileyen faktörlerin önemi de artmaktadır. Sporda genetik altyapı özellikle kuvvet, dayanıklılık, kas kitlesi, kas liflerinin tipi ve oranları ile akciğer kapasitesi üzerinde büyük etki göstermektedir. Spor genetiği çalışmaları, atletik performansa etki eden genlerin belirlenmesi, etki mekanizmalarının aydınlatılması ve atletik performansına olan yatkınlıklarının belirlenmesi alanlarındaki çalışmaların bütününü kapsamaktadır. Atletik performansla ilişkilendirilebilecek genlere örnek olarak; myostatin, eritropoetin, büyüme hormonu, nitrik oksit sentaz, vasküler endotelyal büyüme faktörü, anjiotensin dönüştürücü enzim, anjiotensinojen, monokarboksilat taşıyıcı 1, insüline benzer büyüme faktörü-1, peroksizom proliferatör aktif reseptör, alfa-aktinin-3 gibi genlerini sıralayabiliriz. Bu çalışmanın amacı ise spor bilimlerinde ve sporcu performansinda etkili olan genleri incelemektir.
\end{abstract}

Anahtar Kelimeler: Atletik Performans, Spor, Genetik.

\begin{abstract}
Nowadays, as sporting amateur or professional participation increases, the importance of sportive performance and the factors affecting this performance increase. The genetic background in sports has a great impact on the strength, endurance, muscle mass, muscle fibers and lung capacity. Sports genetics studies include the whole range of studies in determining the genes affecting athletic performance, clarifying the mechanisms of action and determining their susceptibility to athletic performance. Examples of genes that can be associated with athletic performance include; can list genes such as myostatin, erythropoietin, growth hormone, nitric oxide synthase, vascular endothelial growth factor, angiotensin converting enzyme, angiotensinogen, monocarboxylate carrier 1, insulin-like growth factor-1, peroxisome proliferator active receptor, alpha-actinin-3. The aim of this study is to investigate genes that are effective in sports science and sports performance.
\end{abstract}

Keywords: Athletic Performance, Sports, Genetics.

\section{Giris}

Spora amatör veya profesyonel katılım arttıkça sportif performans ve bu performansı etkileyen faktörlerin önemi de artmaktadır. Sporda başarıyı belirleyen faktörler antrenman, genetik, epigenetik, beslenme, motivasyon, ekipman ve diğer çevresel faktörler altında sınıflandırılabilir [1]. Atletik performans, sporcuların herhangi bir sportif aktivitelerinde gösterdikleri mental ve fiziksel performanslarının toplamı olarak kabul edilmektedir. Düzenli antrenman ile geliştirilebilen bir özellik olan atletik performansın hem oluşmasında, hem de gelişmesinde genetik faktörlerin katkısı yapılan çalışmalar ile ortaya konmuştur. Sadece bireysel sporlarda değil, aynı zamanda takım sporlarında da başarı için, genetik yapıya uygun antrenman ve beslenme programlarının oluşturulması şüphesiz ki büyük önem taşımaktadır. Bu yüzden spor genetiği

alanında yapılan çalışmalar son yıllarda sporun büyüyen ekonomisiyle beraber büyük önem kazanmıştır [2].

Spor genetiği çalışmaları, atletik performansa etki eden genlerin belirlenmesi, etki mekanizmalarının aydınlatılması ve atletik performansına olan yatkınlıklarının belirlenmesi alanlarındaki çalışmaların bütününü kapsamaktadır [3]. Sporda genetik altyap1 özellikle kuvvet, dayanıklılık, kas kitlesi, kas liflerinin tipi ve oranları ile akciğer kapasitesi üzerinde büyük etki göstermektedir [4]. Günümüzde insan performans1 ile ilgili, hepsi olmasa da yaklaşık 250 genetik bölge ilişkili bulun $\neg$ muştur. Bu genetik bölgelerin bir kısmı, farklı popülasyonlarda analiz edilmiştir [5].

Atletik performansla ilişkilendirilebilecek genlere örnek olarak; myostatin, eritropoetin, büyüme hormonu, nitrik 
oksit sentaz, vasküler endotelyal büyüme faktörü, anjiotensin dönüştürücü enzim, anjiotensinojen, monokarboksilat taşıyıcı 1, insüline benzer büyüme faktörü-1, peroksizom proliferatör aktif reseptör, alfaaktinin-3 gibi genlerini sıralayabiliriz [6]. Bu çalışmanın amacı ise spor bilimlerinde ve sporcu performansinda etkili olan genleri incelemektir.

\section{IL - 6 (İnterlökin 6)}

Interlökin-6, kromozom 7'nin (7p21) k1sa kolunda bulunan IL-6 geni tarafından kodlanır. IL-6'nın yaklaşık 50 tek nükleotit olduğu bilinmektedir [7]. İnterlökin-6 (IL-6), bağışıklık fonksiyonlarında yer alan çok işlevli bir sitokindir. Son veriler ayrıca, bu proteinin egzersizle indüklenen hasarı takiben kas onarımı ve hipertrofisi süreçlerinde önemli bir rol oynadığını göstermektedir [8]. Buna ek olarak, egzersiz, kastan türetilmiş IL-6 mRNA'sında ve buna bağlı olarak plazma IL-6'daki artışlarda artışa neden olabilir [9]. GG genotipi ve G alleli, elit güç sporcuları ile dayanıklılık sporcuları ve kontrol grubu ile karşılaştırıldığında, kas hipertrofisi ve gücünün anahtar bir fenotip özelliği olduğu elit güç sporcularında allel oranın daha fazla çıkması ile anlaşılmıştır [10]. Bu bağlamda literatürdeki çalışmalara baktığımız zaman Zaken ve ark. (2017) yüzücüler ve koşucular üzerinde yaptıkları çalışmada $G$ alleli oranı kontrol grubunda \% 81, koşucularda $\% 82$ ve yüzücülerde \% 64 bulurken, $\mathrm{C}$ alleli oranı oranı kontrol grubunda $\% 19$, koşucularda $\% 18$ ve yüzücülerde $\% 36$ bulmuşlardır [11]. Diğer yandan Cenikli ve ark. (2016) Türk elit sporcular üzerinde yaptıkları diğer bir çalışmada $\mathrm{G}$ alleli oranı kontrol grubunda \%62.5, sporcularda \%71.1 tespit ederken $\mathrm{C}$ alleli oranı kontrol grubunda \%37.5, sporcularda \% 28.9 tespit etmişlerdir [12]. Ruiz ve ark. (2010) elit güç ve dayanıklılık sporcuları üzerinde yaptıkları çalışmada GG genotipi oranı güç sporcularında $\% 65$, dayanıklılık sporcularında $\% 42$, kontrol grubunda \%42 bulurken, GC genotipi güç sporcularında \%26, Dayanıklılık sporcularında \%43, kontrol grubunda \%46 tespit ederken, CC genotipi güç sporcularında \%9 Dayanıklılı sporcularında \%15 kontrol grubunda \%12 tespit etmişlerdir [13].

Eynon ve ark. (2010) Ulusal ve uluslararası sporcuları karşılaştırdıkları bir çalışmada ise ulusal dayanıklılık sporcularının GG genotipi oranı \% 70, GC genotip oranı $\% 30$, CC genotip oranı \%0, uluslararası dayanıklılık sporcularının GG genotipi oranı \%72,2, GC genotip oranı \%24,1, CC genotip oranı ise $\% 3,7$, ulusal güç sporcularının GG genotipi oranı $\% 76,4$, GC genotip oranı $\% 14,5$, CC genotip oranı $\% 9,1$, uluslararası güç sporcularının GG genotipi oranı \% 57,7, GC genotip oranı $\% 38,5$, CC genotip oranı $\% 3,8$ bulmuşlardır [14].

Son olarak Eider ve ark. (2013) Güç sporcuları üzerinde yaptıkları bir çalışmada Güç sporcularının $G$ alleli oranı $\% 68,67 \mathrm{C}$ alleli oranı \%31,33 bulurken, kontrol grubunun $\mathrm{G}$ alleli oran $1 \% 57,87 \mathrm{C}$ alleli oran $1 \% 42,13$ bulmuşlardır [7].

\section{Angiotensin I-Converting Enzyme (ACE)}

Spor genetiği ile ilgili ilk önemli çalışmalar anjiotensin I dönüştürücü enzim (ACE) geni ile başlamıştır [15]. $\mathrm{ACE}, 17 \mathrm{q} 23$ konumunda bulunur ve ürünü $\mathrm{ACE}$ proteini, gendeki bir varyasyondan dolayı dokularda farklı düzeylerdedir. ACE' nin 16. intronunda bir tekrar dizisinin bulunup bulunmamasına göre genin kisa (delesyonlu, D) ve uzun (insersiyonlu,I) alleleri bulunmaktadır [16]. ACE genotipinin 3 varyansı vardır bunlar I/I ve D/D homozigotları, I/D heterozigotlarıdır. Çalışmaların çoğu D alelinin yüksek kan veya doku ACE enzim seviyeleri nedeniyle kan basıncında artış ile ilişkili olduğunu, ortaya koyarken I allelinin ters etkilere sahip olduğunu bildirmiştir. Bunlara ek olarak, I allel, tip I kas liflerinin oranındaki artış ve kas dayanıklılı̆̆ında artış ile ilişkilidir [17]. Bugüne kadar yapılan, vaka kontrol çalışmalarının çoğu, ACE D / D genotipli bireylerin, kısa mesafe koşuları, uzun atlama, yüksek atlama, disk atma ya da kısa mesafe yüzücüler gibi hız-kuvvetli disiplinlerde çok daha başarılı olduğunu ortaya koymuştur $[18,19]$.

Öte yandan, II genotipli bireyler daha düşük bir ACE serum konsantrasyonuna sahiptir ve orta ve uzun mesafe koşuları, yarış yürüyüşleri ve kayak gibi dayanıklılık ile ilgili disiplinlerde daha fazla başarıya sahiptir [20]. Literatür bilgisine paralel olarak Shahmoradi ve ark. (2014) İranlı atletler üzerinde yaptıkları çalışmada atletlerin I alleli oranı \%47.44, kontrol grubunun \% 38.96 bulurken, atletlerin D alleli oran 52.56 kontrol grubunun ise \%61.04 bulmuşlardır [21]. Ginevičienè ve ark. (2011) Litvanyalı elit sporcular üzerinde yaptıkları çalışmada elit sporcuların II genotipi oranı \%25.9, ID genotipi oran1 47,7, DD genotipi oran1 \%26.4 bulurken, kontrol grubunda II genotipi oranı \%23.6, ID genotipi oranı $\% 38$, DD genotipi oranı $\% 38.4$ bulmuşlardır [22]. Ulucan ve ark. (2015) Futbolcular üzerinde yaptıkları çalışmada I alleli oranı \%38 bulurken, D alleli oranı \% 62 bulmuşlardır [23]. Yusof ve ark. (2015) Malezyalı elit atletler üzerinde yaptıkları çalışmada I alleli oranı kontrol ve dayanıklılık grubunda yüksek çıkarken, D alleli oranı ise kuvvet sporcularında yüksek çıkmıştır [24].

\section{A-Actinin-3 R577X (ACTN 3)}

Yüksek hızda kasılmalar ve yüksek güç üretimi için belirleyici bir faktör olan ACTN3 [25]. RR, RX, XX olarak 3 genotipe ayrılır [26]. Bazı çalışmalar güç ve sprint atletlerinin dayanıklılık atletlerine ve kontrol gurubuna oranla ACTN3 geninin RR genotip sıklığına sahip olurken, dayanıklılık atletlerinde XX genotip sıklığının olduğunu belirtmişlerdir [27,28]. Ek olarak bazı çalışmalar $\mathrm{R}$ allel ile yüksek kas kasılma gücü arasında pozitif bir ilişki olduğunu belirtirken [29-33] diğerleri $\mathrm{X}$ allel dağılımının daha iyi dayanıklılık performansı sağladığını belirtmişlerdir [31-33]. Bu bilgilere paralel olarak Saunders ve ark. (2007) Triatloncular üzerinde yaptıkları bir çalışmada $\mathrm{R}$ alleli hızlı ve orta grup triatloncu grubunda yüksek çıkarken, $\mathrm{X}$ alleli ise yavaş grup ve kontrol grubunda yüksek 
çıkmıştır [34]. Yang ve ark. (2003) Atletler üzerinde yaptıkları bir çalışmada R alleli oranı sprinterlerde $\% 72$ çıkarken, Dayanıklılık sporcularında \%54, kontrol grubunda ise \%56 çıkmıştır. I alleli oranı ise sprinterlerde $\% 28$, dayanıklılık sporcularında $\% 46$ ve kontrol grubunda \%44 çıkmıştır [31]. Orysiak ve ark. (2014) Elit Polonyalı sporcular üzerinde yaptıkları çalışmada R alleli oranı kanocularda \% 58,6, buz hokeyi oyuncularında $\% 62,8, \quad$ yüzücülerde $\% 72,1$, voleybolcularda \%69,4, kontrol grubunda \%64,4 bulurken X alleli oranı kanocularda $\% 41,4$, buz hokeyi oyuncularında $\quad \% 37,2, \quad$ yüzücülerde $\% 27,9$, voleybolcularda \%30,6 kontrol grubunda \%35,6 bulmuşlardır [27]. Kim ve arkadaşları (2014) Sprinterler ve kuvvet sporcuları üzerinde yaptıkları çalışmada $\mathrm{R}$ alleli oranı kuvvet sporcularında \%61,9, sprinterlerde 67,2 , kontrol grubunda $\% 55,4$ bulurken, $\mathrm{X}$ alleli oran ise kuvvet sporcularinda \%38,1, sprinterlerde 32,8 , kontrol grubunda \%44,6 bulmuşlardır [26]. Kıkuchı ve ark. (2014) Japon atletler üzerindeki yaptıkları çalışmada R alleli oranını erkek sporcularda \%55, kadın sporcularda ise $\% 45$ bulurken, $\mathrm{X}$ alleli oranını erkek spoecularda \% 45, kadın sporcularda ise \%55 bulmuşlardır [35]. Öte yandan Yang ve ark. (2016). Çinli elit atletler üzerinde yaptıkları çalışmada RR Genotip oranı sprinter ve güç sporcularında \%49.1 dayanıklılık sporcularında \% 31.8 kontrol grubunda $\% 26.0$ bulunurken, RX Genotip oranı sprinter ve güç sporcularında \%45.8 dayanıklılık sporcularında \%36.4 kontrol grubunda \% 40.0 çıkarken, XX Genotip oranı ise sprinter ve güç sporcularında \% 5.1 dayanıklılık sporcularında \%31.8 kontrol grubunda \% 34.0 bulmuşlardır [36].

\section{Angiotensinogen (AGT M 235 T )}

Renin-anjiyotensin sistemi (RAS), kan basıncı dengesinin, insan vücudundaki su ve tuz dengesinin, sporcu performansında iyileşme ve çeşitli popülasyonlarda egzersize ilişkili önemli faktörlerin korunmasında kilit bir rol oynar AGT proteini, lokus 1q42'deki 1. kromozom üzerinde yer alan AGT geni tarafindan kodlanır [37]. Daha önce yapılan çalışmalarda, gen içinde M235T (rs699; ekzon 2'de 4.072 pozisyonunda $\mathrm{C} / \mathrm{T}$ nükleotid geçişi) varyasyonunun tanımlanmış birçok polimorfik bölgeden birinin farklı AGT seviyeleri ile ilişkili olduğu ortaya çıkmıştır. Sonuç olarak, polimorfizm son zamanlarda sporla ilgili araştırma bağlamında tanımlanmıştır [3841].

Spesifik olarak, treonin (T) tortusunun, 235 amino asidinde metionin (M) ile yer değiştirmesiyle sonuçlanan C alleli, daha yüksek ANG II seviyeleri ile korelasyona girmiştir ve sonuç olarak, istirahatte artmış kan basıncı veya yoğun egzersize karşılık gelir. Protein seviyesinde ANG II, güç ve güç ile ilişkili sporlar için faydalı olan bir iskelet kas büyüme faktörü olarak görev yapar [37]. Bunun sonucunda literatürdeki örnek çalışmalara göz attığımız zaman Gallego ve ark. (2009) Güç sporcuları üzerine yaptıkları çalışmada TT genotip oranı güç sporcularında \%33,3, dayanıklılık sporcularında \%34, kontrol grubunda \%34,5 bulurken, TC genotipi oranı güç sporcularında $\% 31,7$, dayanıklılık sporcularında \%50, kontrol grubunda \%49,6 çıkarken, CC genotipi oranı güç sporcularında \% 34,9, dayanıklılık sporcularında \% 16, kontrol grubunda \% 16 çıkmıştır [39]. Zarebska ve ark. (2013) Güç ve dayanıklılık sporcularını karşılaştırdıkları çalışmada T alleli oranı güç sporcularında $\% 44,5$, dayanıklılık sporcularında \%61,0, kontrol grubunda $\% 59,9$ bulurken, C alleli oranını güç sporcularında $\% 55,5$, dayanıklılık sporcularında \%39,0, kontrol grubunda \%40,1 bulmuşlardır [41].

\section{Nitric Oxide Synthase 3 (Nos 3)}

Nitrik oksit (NO) önemli bir kardiyovasküler regülatördür, pulmoner dolaşımdaki akış düzenlerini modüle eder ve iskelet kasları ve kardiyak fonksiyon üzerindeki etkilerle egzersiz performansını etkiler. Endotelyal NO sentaz kalpteki ana NO kaynağıdır ve genetik varyantları NO biyoyararlanımı üzerinde bir etkiye sahip olabilir [42]. Farklı klinik koşullarda NOS3 geninin çeşitli genetik varyantlarının incelenmesi, anlamlı etnik ve genotip dağılımı ile ilgili farklılıklar göstermiştir. En yaygın olarak incelenen üç NOS3 polimorfizmi, ekson 7'deki G894CT (Glu298Asp), intron 4'teki 4a / 5b 27-bazepair değişken tandem tekrarları ve promoter bölgesindeki T-786C varyantını içerir [43]. Nitrik oksit (NO) iskelet kas fonksiyonunun kontrolünü etkiler, egzersiz sırasında iskelet kasının glukoz alımını arttırır ve mitokondriyal ATP üretimini artırır ve tüm bu süreçler kas gücünü modüle eder [44].

Kan akışının regülasyon performansında oynadığ sınırlayıcı rol göz önüne alındığında,NOS3 polimorfizmi de elit dayanıklılık sporcularının performanslarını etkileyebilir [45]. Literatür taraması yaptığımız zaman ise verdiğimiz bilgilere paralel olarak Cięszczyk ve ark. (2010). Elit ve elit olmayan kürekçiler üzerinde yaptıkları çalışmada $G$ alleli oranı elit kürekçilerde \%73,5, elit olmayan kürekçilerde 79,3, kontrol grubunda \%67,2 tespit ederken, T alleli oranı elit kürekçilerde $\% 26,5$, elit olmayan kürekçilerde 20,7, kontrol grubunda \% 32,8 tespit etmişlerdir [46]. Eider ve ark. (2014) Polonyalı sporcular üzerinde yaptıkları çalışmada $\mathrm{G}$ alleli oranı kuvvet sporcularında \% 78,9, karışık grupta $\% 76,5$, dayanıklılık grubunda $\% 75,9$, kontrol grubunda \%66,5 bulurken, T alleli oranı kuvvet sporcularında $\%$ 21,1, karış1k grupta \%23,5, dayanıkl1l1k grubunda $\% 24,1$, kontrol grubunda $\% 33,5$ bulmuşlardır [47]. Saunders ve ark. (2006) Triatloncular üzerinde yaptıkları çalışmada GG genotipi oranı hizlı triatlon grubunda $\% 35$, orta triatlon grubunda $\% 40,4$, yavaş triatlon grubunda, \%46,9 kontrol grubunda \%39,3 çıkarken, GT genotipi oranı hızlı triatlon grubunda $\% 51,1$, orta triatlon grubunda $\% 45,2$, yavaş triatlon grubunda, $\% 40,7$ kontrol grubunda $\%$ 44,2 bulurken, TT genotipi oranı hızlı triatlon grubunda $\% 14$, orta triatlon grubunda $\% 14,4$, yavaş triatlon 
grubunda, \%12,4 kontrol grubunda \%16,6 bulmuşlardır [48].

\section{Peroxisome Proliferator-Activated Receptor 0 (PPAR $\alpha)$}

Peroksizom proliferatör aktive reseptörler (PPAR $\alpha$ ), lipit metabolizması ve glikoz homeostazında rol oynayan nükleer hormon reseptörü süper ailesinin üyeleridir İnsanlarda, PPAR $\alpha$ ekspresyonu tip II kas liflerine göre tip I'de daha yüksektir. Kas PPAR $\alpha$ içeriği, tip I liflerinde en yüksek artışı, dayanıklılık antrenmanı ile artırılabilir. Dayanıklılık egzersizi, lipid metabolizmasında yer alan proteinlerin ekspresyonunu artırarak yağ asidi oksidasyon kapasitesini artırır. Yağ asitleri, dayanıklılık egzersizi sırasında birincil enerji kaynağıdır. Bu nedenle, daha yüksek bir PPAR $\alpha$ protein içeriğinin dayanıklılık tipi egzersiz için faydalı olduğu önerilmektedir [49,50]. Daha spesifik olarak, bir PPAR $\alpha$ gen ekspresyonunun ve dolayısıyla intron $7 \mathrm{G}$ alelelinin dayanıklılık performansıyla ilişkili olması beklenebilir.

Öte yandan, C allel taşıyıcılarının, kas metabolizmasında esas olarak glikoz kullanılarak yoğun anaerobik (güç) performansa daha yatkın oldukları düşünülmektedir [51]. Bu konu ile ilgili örnek çalışmalar ise Gineviciene ve ark. (2012) Futbolcular üzerinde yaptıkları çalışmada futbolcuların mevkilerine göre $\mathrm{G}$ alleli oranı forvetlerde \%72,7, defans oyuncularında $\% 84,1$, orta saha oyuncularında $\% 82,7$, kalecilerde $\% 76,5$, kontrol grubunda $\% 85$ bulurken, C alleli oranı forvetlerde $\% 27,3$, defans oyuncularında $\%$ 15,9 , orta saha oyuncularında $\% 17,3$, kalecilerde $\%$ 23,5, kontrol grubunda \% 15 bulmuşlardır[52]. Proia ve ark. (2014) İtalyan futbolcular üzerinde yaptıkları çalışmada futbolcuların \%64' ü GG genotipine \%32'si GC genotipine \%4' ü CC genotipine sahip olduğu bulurken, kontrol grubunun \%48' i GG genotipine \% 44,5' u GC genotipine \%7,5' i CC genotipine sahip olduğunu bulmuşlardır [53]. Eynon ve ark. (2010) Sprint ve dayanıklılık atletleri üzerinde yaptığı çalışmada sprinterlerin \%1' i GG genotipine \%27'si GC genotipine \%62' si CC genotipine sahip olduğunu tespit ederken, dayanıklılık sporcularının \%10'u GG genotipine \%28' si GC genotipine \%62'si CC genotipine sahip olduğunu bulurken, kontrol grubunun $\% 4$ ' Ü GG genotipine \%28'i GC genotipine \%68' inin CC genotipine sahip olduğu bulmuşlardır [54]. Tural ve ark. (2014) Dayanıklılık sporcuları üzerinde yaptıkları çalışmada dayanıklılık sporcularının \%63,3' ü GG genotipine $\% 31,7$ 'si GC genotipine $\% 5$ ' i CC genotipine sahip olduğunu bulurken, kontrol grubunun \%38,2' si GG genotipine $\% 49,1$ 'i GC genotipine $\% 12,7$ si CC genotipine sahip olduğunu bulmuşlardır [55].

\section{Nuclear Respiratory Factor 1 and 2 (NRF1 and NRF 2)}

Nükleer solunum faktörü olan NRF1 ve NRF2 genleri mitokondrial biyogenez ve solunumda koordinasyonu sağlamaktadır [4]. Dayanıklılık antrenmanı, iskelet kas dokusunda mitokondriyal biyogenezi uyarır, bu da solunum kapasitesinin artmasına ve antrenman sirasında artan ATP oluşumunun artmasına neden olur [56,57]. Mitokondrinin biyogenezi, çoğu nükleer genomda bulunan çok sayıda genin ekspresyonunu gerektirir. mtDNA'nın protein kodlama kapasitesi aslında nükleer düzenleyici faktörlerin nükleer mitokondriyal etkileşimleri yönetmede önemli bir rol oynamasını gerektiren 13 solunum alt birimi ile sinırlıdır [58]. Bu faktörlerden biride solunum alt birimleri ve mitokondriyal transkripsiyon ve replikasyon makinelerinin bileşenlerini kodlayan nükleer genler üzerinde hareket eden nükleer solunum faktörü 1'dir (NRF 1) [59,60]. Nükleer respiratuar faktör 2 (NRF2) proteini, hedef genlerin promotöründe antioksidan tepki elementini (ARE) tanıyan Cap-N-Collar transkripsiyon faktörü ailesinin bir üyesidir [61]. NRF2 proteinini kodlayan NRF2 geninin (GABPB1) solunum kapasitesini artırdığı ve egzersiz sırasında ATP üretim hızını artırdığı öne sürülmüştür [60,62]. Maksimal oksijen tüketimi (VO 2max), için yapılan bir genom taraması bu kromozom lokalizasyonunun Dayanıklılık antrenmanı ile yüksek ilişkili olabileceğini göstermiştir [63]. NRF2 geninde translasyon başlatıcı sekansta (ATG), taşıyıcılarda görülen bir polimorfizm koşu ekonomisinde şiddetli antrenmana cevapta, taşıyıcı olmayanlara göre avantaj sağlamakta ve 1-alt-biriminde intron 3'de, oksijen tutulumu ve A / G polimorfizmi arasında hafif bir ilişki bulunmuştur. Bu polimorfizmde, $\mathrm{G}$ allelinin, dayanıklılık antrenmanına yanıt olarak daha yüksek oksijen alımı değerleri ile ilişkili olduğu bulunmuştur $[64,4]$.

Bu bağlamda literatürdeki çalışmalara baktığımız zaman Eynon, ve ark. (2010) Atletizm sporcuları üzerinde yaptıkları çalışmada dayanıklılık sporcularının \%58'i sprinterlerin \%35'i kontrol grubunun \%43'ü AA genotipine sahip olduğunu tespit ederken, dayanıklılık sporcularının \%37'si sprinterlerin \%47'si kontrol grubunun \%46'sının AC genotipine sahip olduğu bulunurken, dayanıklılı sporcularının \%5'i sprinterlerin \%18'i kontrol grubunun \%11'inin CC genotipine sahip olduğu bulumuşlardır[61]. Eynon ve ark. (2013) İspanyol atletler üzerinde yaptıkları çalışmada dayanıklılık sporcularının \% 48'i sprinterlerin $\% 13$ '̈ kontrol grubunun \%21'inin AA genotipine sahip olduğunu tespit ederken, dayanıklılık sporcularının \% 24'ü sprinterlerin \%66's1 kontrol grubunun \%60'nın AC genotipine sahip olduğu bulurken, dayanıklılık sporcularının \%28'i sprinterlerin \%21'i kontrol grubunun \%19'unun CC genotipine sahip olduğu bulmuşlardır [65]. Eynon ve ark. (2009) dayanıklılık ve sprint sporcuları üzerinde yaptıkları bir başka çalışmada A alleli oranı dayanıklılık sporcularında \%94, sprinterlerde 99, kontrol grubunda ise \%99 bulurken, G alleli oranı dayanıklılık sporcularında $\% 6$, sprinterlerde $\% 1$, kontrol grubunda \%1 bulmuşlardır [66].

\section{8. $\beta$-adrenergic receptor (ADRB GEN AIILESİ)}

$\beta$-Adrenerjik reseptörler ( $\beta$ ARs), doğal olarak oluşan katekolaminler tarafindan uyarılan $\mathrm{G}$ proteinine bağlı 
reseptörlerin bir familyasının üyeleridir. İnsanlarda, üç tip $\beta$ AR bilinir: $\beta 1 \mathrm{AR}, \beta 2 \mathrm{AR}$ ve $\beta 3 \mathrm{AR}$. Bu reseptörleri kodlayan genler, metabolik ve kardiyovasküler fenotipler ile ilişkilidir, insanların egzersiz kapasitesini etkilemeye adaylarındandır [67].

\section{1. $\beta 2$-adrenergic receptor (ADRB2)}

Elit dayanıklılı performansı multifaktöriyel ve oligogenik bir özelliktir. Ancak, bu karmaşık fenotipe katkıda bulunan tek genetik belirteçler hakkında çok fazla şey bilinmemektedir. Adrenerjik reseptörler çeşitli performans esaslı yollarda yer almaktadır ve bu nedenle performans fenotipleri için aday genler olarak özellikle ilgi çekicidir. Özellikle $\beta 2$-adrenerjik reseptör (ADRB2) geni, enerji harcamalarının düzenlenmesine ve insan adipoz dokusundan lipit harekete geçirilmesine katkısı nedeniyle, dayanıklılık performans düzeylerindeki değişiklik için olası bir adaydır. Buna ek olarak, ADRB2 kardiyovasküler fonksiyonun düzenlenmesinde temel bir role sahiptir. Bu fizyolojik etkilere dayanarak, çeşitli çalışmalar ADR-reseptör fonksiyonunu değiştirdiği bilinen genetik polimorfizmlerin rolünü araştırmıştır. $\mathrm{Bu}$ bulgulara dayanarak, ADR recepreseptörlerinin işlevlerindeki ince değişikliklerin bile kardiyovasküler, solunum veya metabolik kontrolde değişikliklere yol açabileceğini özetliyoruz [68,69,70].

\subsection{B3-Adrenergic Receptor (ADRB3)}

$\beta 3 \mathrm{AR}$ geninin (ADRB3) Egzersiz performansındaki potansiyel rolü hakkında daha az şey bilinmektedir. $33 \mathrm{AR}$ genin adipoz dokuyu aktive etmek ve böylece lipolizi ve termojenezi uyarmak için $G$ aleline bağlandığı bilinmektedir. ADRB3Trp64Arg polimorfizminin (rs4994) Arg aleli, obez kişilerde kilo alma ile ilişkilendirilmiştir [67].

\section{Adenosine Monophosphate Deaminase 1 (AMPD1)} Adenosin monofosfat deaminaz 1 (AMPD), iskelet kaslarında enerji üretiminde rol alır [71]. AMPD1 geni tarafindan kodlanan AMPD, egzersiz sirasinda iskelet kas enerji metabolizmasının önemli bir düzenleyicisidir [72]. AMPD'nin iskelet kasına özgü izoformu (M), 1p13-p21 kromozomunda bulunan AMPD1 geni tarafindan kodlanır [73]. AMPD1 geninin üç genotipi bulunmaktadır (CC, TC ve TT). AMPD enzimi, AMP'nin (adenosin monofosfat) IMP'ye (inosin monofosfat) deaminasyonunu katalize ederek ADP (adenosin difosfat) birikimini azaltır ve miyokinaz reaksiyonunun dengesini ATP oluşumuna doğru kaydırır. AMPD1 geni, yüksek yoğunluktaki fiziksel egzersiz sırasında hücresel enerji metabolizmasının önemli bir düzenleyicisidir [74]. Cieszczyk ve ark. (2012) Polonyalı sporcularda yaptıkları çalışmada CC Genotip oranı kısa mesafe koşucularda \%89.59, kısa mesafe yüzücülerde \%88.90, ağırlık kaldıranlarda \% 89.29, kontrol grubunda \%75 bulurken, CT Genotip oranı kısa mesafe koşucularda \%10.41, kısa mesafe yüzücülerde \%11.10, ağırlık kaldıranlarda \%10.71, kontrol grubunda \%23.75 tespit ederken, TT Genotip oranı kısa mesafe koşucularda \%0, kısa mesafe yüzücülerde $\% 0$, ağırlık kaldıranlarda $\% 0$, kontrol grubunda \%1.25 tespit etmiştir [75]. Ginevičienè ve ark. (2014) Litvanyalı atletlerle yaptıkları çalışmada CC genotipi oranı dayanıklılık grubunda $\% 72,9$, Sprint ve güç grubunda $\% 86,3$, karışık grupta $\% 67,1$, kontrol grubunda \%72,2 bulurken, CT genotipi oranı dayanıklılık grubunda $\% 25,9$, Sprint ve güç grubunda $\%$ 11,8, karışık grupta \%32,9, kontrol grubunda \%25,5 tespit ederken, TT genotipi oranı dayanıklılı grubunda $\% 0$, Sprint ve güç grubunda $\% 0$, karışık grupta $\% 0$, kontrol grubunda \%2,4 tespit etmiştir [76]. Cieszczyk ve ark. (2011) kürek sporcularıyla yaptıkları çalışmada CC genotipi oranı bütün kürek sporcularında \%88,19, elit kürek sporcularında \%90,91, elit olmayan kürek sporcularında \%86,75, kontrol grubunda \%75,31 tespit edilirken, CT genotipi oranı bütün kürek sporcularında $\% 11,81$, elit kürek sporcularında \%9,09, elit olmayan kürek sporcularında \%13,25, kontrol grubunda \%23,10 bulunurken, TT genotipi oranı bütün kürek sporcularında $\% 0$, elit kürek sporcularında $\% 0$, elit olmayan kürek sporcularında \%0, kontrol grubunda $\%$ 1,59 bulmuştur [77].

\section{Bradykinin $\beta 2$ Receptor (BDKRB2)}

Bradykinin kinins olarak bilinen peptidlerden biridir. $\mathrm{Bu}$ peptit kallikreinlerin proteolitik aktivitesi ile kininogenlerden salınan önemli bir vazodilatatör olarak kabul edilmiştir [78]. Kininlerin başlıca biyolojik etkileri, bradikinin reseptörleri tarafından yönlendirilir. Bradykinin reseptörleri geniş bir doku aralığında yaygındır. BDKRB2, endotel hücreler, düz kas tarafından yapısal olarak eksprese edilen bir reseptör alt tipidir [79,80]. BDKRB2 aktivasyonu, fiziksel aktivite sırasındaki iskelet kasının glikoz alımının ve kaslardaki kan akışını arttırdığı için kişinin daha yüksek dayanıklılık performansı sergilemesini sağlar [81].

Zmijewsk1 ve ark. (2015) müsabık yüzücülerle yaptıkları çalışmada $+9 /+9$ genotipi erkek yüzücülerde 19 kişide, kadın yüzücülerde 10 kişide, kontrol grubunda 69 kişide tespit ederken, -9/+9 genotipi erkek yüzücülerde 25 kişide, kadın yüzücülerde 27 kişide, kontrol grubunda 112 kişide bulurken, -9/-9 genotipi erkek yüzücülerde 8 kişide, kadın yüzücülerde 11 kişide, kontrol grubunda 26 kişide tespit etmiştir[78]. Eynon ve ark. (2011) elit atletler yaptıkları çalışmada +9/+9 genotipi dayanıklılık sporcularında \% 29,7, sprinterlerde \% 28,4, kontrol grubunda \% 26,3 bulunurken, , -9/+9 genotipi dayanıklılık sporcularında $\%$ 54,1, sprinterlerde \%49,4, kontrol grubunda \% 55,4 tespit ederken, , $-9 /-9$ genotipi dayanıklılık sporcularinda \%16,2, sprinterlerde \%22,2, kontrol grubunda \%18,3 bulmuştur [82]. Saunders ve ark. (2006) demir adam triatloncularıyla yaptıkları çalışmada -9/-9 genotipi hızlı triat grubunda $\% 29,9$ orta triat grubunda $\% 22,6$, yavaş triat grubunda $\% 28,3$, kontrol grubunda \%19,3 bulurken, $-9 /+9$ genotipi hızlı triat grubunda $\% 45,8$ orta triat grubunda $\% 49,6$, yavaş triat grubunda \%46,9, kontrol grubunda \%57,9 tespit ederken, +9/+9 genotipi hizlı triat grubunda $\% 24,3$ orta 
triat grubunda \%27,8, yavaş triat grubunda \%24,8, kontrol grubunda \%22,8 tespit etmiştir[48].

\section{Muscle Specific Creatine Kinase (CKMM)}

Kreatin kinaz (CK), bir fosfatın fosfokreatinden adenosin difosfata geri dönüşümlü transferini katalize ederek, büyük miktarda enerji gerektiren beyin ve kas gibi dokularda adenosin trifosfat üretmektedir. Kas spesifik kreatin kinaz (CKMM) enzimi, kas hücrelerinin enerji homeostazında hayati bir rol oynayan kreatin kinazın (CK) çeşitli doku spesifik izozimlerinden biridir[83,84]. $\quad \mathrm{Bu}$ izozim, iskelet kaslarının karakteristirik yapısını oluşturur, fakat CKM aktivite seviyesi, tip I liflere (yavaş kasılanlar) göre tip II'de (hızlı kasılanlarda) anlamlı derecede daha yüksektir[85]. Kas spesifik CK, 19q13.2 - 13.3 lokusundaki 19. kromozom üzerinde yer alan CKM geni tarafindan kodlanır.Gen 17.5 kilobaz çifti üzerinde uzanır. 8 ekson ve 7 intron içerir[86]. Fedotovskaya ve ark. (2013) Rus ve Polonyalı dövüş sporcularıyla yaptıkları çalışmada AA genotipi judocularda $\% 34,5$, güreşçilerde $\% 36,7$, boksörlerde \%37,3, kontrol grubunda $\% 42,1$ bulurken, AG genotipi judocularda $\% 37,9$, güreşçilerde $\% 44,3$, boksörlerde \%49, kontrol grubunda \% 44,6 tespit ederken, GG genotipi judocularda $\% 27,6$, güreşçilerde $\%$ 19,0, boksörlerde \%13,7, kontrol grubunda \% 13,3 tespit etmiştir[87]. Eider ve ark. (2015) Rus ve Polonyalı kürekçilerle yaptıkları çalışmada Polonyalı kürekçilerde AA genotipi \%44,9, AG genotipi \% 44,9, GG genotipi \% 10,2 bulunurken, Polonyalı kontrol grubunda AA genotipi \%50,9, AG genotipi \% 42,8, GG genotipi \%6,3 tespit ederken, Rus kürekçilerde AA genotipi \%43, AG genotipi \% 38,7, GG genotipi \% 18,3 bulurken Rus kontrol grubunda AA genotipi \% 42,5, AG genotipi \%44,4, GG genotipi \%13,1 tespit etmiştir[88].

Fedotovskaya ve ark. (2012) farklı branşlardaki sporcularla yaptıkları çalışmada bütün branşlardaki AA genotipine sahip sporcu sayısı 196 kişi, AG genotipine sahip sporcu sayısı 131 kişi, GG genotipine sahip sporcu sayısı 57 kişi olduğu tespit ederken, konrol grubunda AA genotipine sahip kişi sayısı 493 kişi, AG genotipine sahip kişi sayısı 473 kişi, GG genotipine sahip kişi sayısı 150 olduğunu tespit etmiştir [89].

\section{Guanine Nucleotide Binding Proteins (GNB3)}

Heterotrimerik G-proteinleri ailesine ait olan guanin nükleotid bağlayıcı proteinin alt birim beta 3'ü kodlar. $\mathrm{Bu}$ kompleksler, metabotropik reseptörler ile bağlantılıdır ve reseptörler ve hücre içi efektörler arasındaki hücre sinyallerinin transdüksiyonundan sorumludur [90]. $\beta 3$ alt birimi, tüm insan dokusunda bulunur ve hücre içi sinyal iletim sisteminin anahtar elemanlarından biridir [91]. Heterotrimerik Gproteinlerinin $\beta 3$-alt birimini kodlayan GNB3 geninin eksonu 10 pozisyonunda $825(\mathrm{C} \rightarrow \mathrm{T})$ pozisyonunda bir polimorfizm tarif edilmiştir. 825T allelinin ekspresyonu, ekson 9'un alternatif bir şekilde birleştirilmesinden kaynaklanmaktadır. $\mathrm{Bu}$ tip birleştirme, sırasıyla Gprotein aktivasyonunu arttıran 41 amino asidi ortadan kaldırmaktadır [92]. Bu polimorfizm, hipertansiyon dahil olmak üzere multigenik bozukluklarla ilişkilendirilmiştir.

İnsan değişkenliğini ve egzersiz fenotiplerini açıklamak için aday gösterilmektedir. Ayrıca egzersiz sırasında maksimum oksijen tüketiminin (VO2 maks.) ölçümü, kardiyorespiratuvar uygunluğun değerlendirilmesi için bir standarttır Faruque ve ark. 2009). [93,94]. Ruiz ve ark. (2011) atletlerle yaptıkları çalışmada CC genotipi kontrol grubunda \% 38,8, dayanıklılık sporcularında \% 32,8, kuvvet sporcularında \%33,6 bulurken, CT genotipi kontrol grubunda $\% 49,7$, dayanıklılık sporcularında $\%$ 54, kuvvet sporcularında \%56 tespit ederken, TT genotipi kontrol grubunda \%11,5, dayanılkl11k sporcularında \%13,2, kuvvet sporcularında \% 10,4 tespit etmiştir[95]. Sawczuk ve ark. (2014) Polonyalı elit atletlerle yaptıkları çalışmada $\mathrm{CC}$ genotipi oranı dayanıklılık sporcularında $\% 48$, kuvvet ve güç sporcularında \%41, kontrol grubunda \%43,8 bulurken, CT genotipi oranı dayanıklılık sporcularında \%44,7, kuvvet ve güç sporcularında $\% 49$, kontrol grubunda $\%$ 48 tespit ederken, TT genotipi oranı dayanıklılık sporcularında $\% 7,3$, kuvvet ve güç sporcularında $\% 10$, kontrol grubunda \%8,2 tespit etmiştir[96].

\section{Hypoxia İnducible Factor $1 \alpha$ (HIF1A)}

Memeli hücrelerinde, oksijen homeostazisi, transkripsiyon faktörü hipoksi-indüklenebilir faktör-1 (HIF-1) ile düzenlenir. HIF-1, oksijen ve besinlerin verilmesinde rol oynayan düşük oksijen gerginliği (anjiyogenez, glukoz, metabolizması, glikoz taşınması, vazomotor kontrol ve eritropoiezde yer alan genler dahil) hücrelere veya bu substratların hücresel kullanımını kontrol etmek için hücre adaptasyonu sağlayan genlerin ekspresyonunu düzenler [97]. Bazı kanıtlar, kasdaki lokal hipoksinin ortaya çıkmasının egzersiz sırasında miyosit içindeki oksijen basıncında bir düşüşe neden olduğunu göstermektedir. Bu düşüş ise insan iskelet kasında HIF1A aracılığıyla sinyal yolunun indüksiyonuna neden olmakta, böylece enerji üretimi için oksidatif yolların kullanımının artmasına neden olmaktadır [98]. HIF-1 $\alpha$ geni esas olarak oksijen tüketimi ile ilişkilendirilmesine rağmen, oksijenden bağımsız mekanizmalarla da düzenlenmektedir. Örneğin, HIF-1 $\alpha$ 'nın insülin benzeri büyüme faktörü (IGF) -1'ü aktive ettiği bilinmektedir [99]. Cieszczyk ve ark. (2012) elit kürekçilerle yaptıkları çalışmada Pro/Pro genotipi elit kürekçilerde \%65,91, elit olmayan kürekçilerde \%67,41 bulurken, Pro/Ser genotipi elit kürekçilerde \%31,82, elit olmayan kürekçilerde \%32,53 tespit ederken, Ser/Ser genotipi elit kürekçilerde \%2,27, elit olmayan kürekçilerde \%0 tespit etmiştir [100].

Gabbasov ve ark. (2013) Rus kuvvet sporcularıla yaptıkları çalışmada Pro/Pro genotipi ağırlık kaldıran sporcularda 90 kişide, güreşçilerde 60 kişide, kontrol grubunda 1207 kişide tespit ederken, Pro/Ser genotipi ağırlık kaldıran sporcularda 32 kişide, güreşçilerde 25 kişide, kontrol grubunda 199 kişide bulurken, Ser/Ser 
genotipi ağırlık kaldıran sporcularda 1 kişide, güreşçilerde 1 kişide, kontrol grubunda 7 kişide bulmuştur [99].

\section{4. İnsulin-Like Growth Factor 1 (IGF-1)}

İnsülin benzeri büyüme faktörü-1 (IGF-1) egzersizle ilişkili kas büyümesinde ve gelişiminde anahtar rol oynamaktadır. IGF-1 en önemli etkilerinden bir tanesi boy uzaması ile ilgilidir. IGF-1 geninde oluşan mutasyonlar ve silinmeler çocukların boyunun uzamasını engellemektedir. Ayrıca IGF-1 genindeki değişimler kanser riski, obezite, yaşlanma ve insan ömrünün uzaması gibi faktörleri etkilemektedir. IGF-1 antrenman ile ilişkisi kas hipertrofisini elde edilmesinde etkili olması ve kas hasarı onarımı ve yenilenmesine büyük rol oynadığı bilinmektedir [101,102]. Zaken ve ark. (2013) elit atletlerle yaptığı çalışmada dayanıklılık sporcularının \%62'si CC genotipine, \%33'ünü CT genotipine, \%5'nin TT genotipne sahip olduğunu bulurlarken, kuvvet sporcularının \%68'i CC genotipine, \%38'i CT genotipine, \%4’ü TT genotipne sahip olduğunu bulmuşlardır. Kontrol grubunun ise \%75'i CC genotipine, $\% 25$ 'i CT genotipine, \%0 TT genotipne sahip olduğunu tespit etmişlerdir[101]. Zaken ve ark. (2016) elit koşucular, ağırlık çalışanlar ve yüzücülerle yaptıkları çalışmada uzun mesafe koşucularının AA genotipi $\% 41$, AG genotipi $\% 43$, GG genotipi oranı $\% 16$ olarak belirlerken, kısa mesafe koşucularının ve atlayıcıların AA genotipi \%33, AG genotipi \%43, GG genotipi oranı \%24, ağırlık çalışanların AA genotipi $\% 37$, AG genotipi $\% 54$, GG genotipi oranı $\% 9$, k1sa mesafe yüzücülerin $\mathrm{AA}$ genotipi $\% 34, \mathrm{AG}$ genotipi $\% 52$, GG genotipi oranı $\% 14$, uzun mesafe yüzücülerin AA genotipi \%36, AG genotipi \%46, GG genotipi oranı $\% 18$, kontrol grubunun AA genotipi \%41, AG genotipi $\% 45$, GG genotipi oranı \%14 olarak belirlemişlerdir [103].

\section{5. İnsulin-like Growth Factor 2 (IGF 2)}

IGF2, karaciğer tarafindan salgılanan, kanda dolaşan ve insülinle yapısal benzerliği paylaşan üç protein hormonundan biri olan tek zincirli bir polipeptittir. IGF 2'nin insanın büyümesi ve insülinin görevlerine benzer aktiviteleri vardır. IGF2, IGF1 gibi iskelet kaslarının gelişmesinde ve büyümesinde önemli rol oynar [104]. IGF2 geni, insülin benzeri büyüme faktörü 2'yi kodlar. $\mathrm{Bu}$ genin kas hasarı ile ilişkili olduğu ve antrenman sonrası kas kütlesinin artmasına ve yeni oluşacak olan yüklere adaptasyonu sağladığı düşünülmektedir [105,106]. Zaken ve ark. (2017) elit koşucular, ağırlık çalışanlar ve yüzücülerle yaptıkları çalışmada uzun mesafe koşucularının AA genotipi \%40, AG genotipi $\% 50$, GG genotipi oran1 \%10 olarak belirlerken, kısa mesafe koşucularının AA genotipi \%43, AG genotipi $\% 44$, GG genotipi oranı \%69, ağırlık çalışanların AA genotipi $\% 28$, AG genotipi $\% 4$, GG genotipi oran $\% 9$, kısa mesafe yüzücülerin AA genotipi $\% 58$, AG genotipi $\% 32$, GG genotipi oranı $\% 10$, uzun mesafe yüzücülerin AA genotipi \%41, AG genotipi \%52, GG genotipi oran $\% 7$, kontrol grubunun AA genotipi \%49, AG genotipi
$\% 43$, GG genotipi oranı \%8 olarak belirlemişlerdir[104]. Ellis ve ark. (2017) ağırlık çalışan erkekler yaptıkları çalışmada sporcuların AA genotipini $\% 45.02$, AG genotipini \% 18.48, GG genotipini \% 36.49 olarak tespit etmişlerdir[106].

\section{Myosin Light Chain Kinase (MLCK)}

MLCK genleri myosin düzenleyici hafif zincirinin fosforilasyonundan sorumlu olan MLCK proteinlerini kodlar [107]. İskelet kası kasılması sırasında düzenleyici bir rol oynar bununla birlikte sarkomerik proteinlerin aktinler ve miyozinler arasında çapraz köprü kurmasını sağlar. $\mathrm{Ca} 2+$ 'nin tropomiyosintroponine bağlanması ve iskelet kası kasılmasının birincil düzenleyicisidir. Bununla birlikte kuvvet gelişiminde de önemli bir role sahiptir [108]. Clarkson ve ark. (2005) sedanter bireylere yaptıkları çalışmada katılımcıların CC genotipi \%63,4, CT genotipi \%32,7, TT genotipi \%3,9 olarak belirlemişlerdir [109].

\section{Myostatin (MSTN)}

Önceden büyüme farklılaşması faktörü 8 (GDF-8) olarak bilinen myostatin, vücuttaki dokuların büyümesini ve farklılaşmasını kontrol eden transforme edilmiş büyüme faktörü süper $\beta$ proteinlerin ailesine ait bir proteindir [110]. MSTN geni, temel olarak iskelet kas kas kütlesini geliştirme ve kuvveti artırmaya yarayan spesifik bir gendir [111]. Zaken ve ark. (2015) elit atletler ve yüzücülerle yaptıkları çalışmada Atletlerin Lys-Lys genotipi \%85,5, Lys-Arg genotipi \% 14, Arg-Arg genotipi \% 0,5, Yüzücülerin Lys-Lys genotipi \%91,3, Lys-Arg genotipi \%7,5, Arg-Arg genotipi \%1,2, Kontrol grubunun Lys-Lys genotipi \% 89,8, Lys-Arg genotipi \% 8,5, Arg-Arg genotipi \%1,7 olarak tespit etmişlerdir[110]. Li ve ark. (2014) sedanter erkeklere 8 hafta hipertrofi antrenmanı yaptırdıkları çalışmada AA genotipi \%86,17, AT genotipi \%12,77, TT genotipi \%1,06 belirlemişlerdir[112].

\section{Vascular Endothelial Growth Factor (VEGF)}

Aerobik antrenmanlar anjiyogenez olarak bilinen yeni kılcal damarların gelişimi de dahil bazı iskelet kaslarının da antrenmana adaptasyonunu gerçekleştirir. Egzersize bağlı anjiyogenez, O2'nin difüzyonu için mevcut kılcal yüzey alanını arttırır ve sonuçta aerobik kapasite artmış olur [113]. Vasküler endotel büyüme faktörü (VEGF), anjiyogenezin ana düzenleyicilerinden biri olarak tanımlanmıştır, çünkü endotel hücre çoğalması ve göçünde rol oynar. Ayrıca VEGF, iskelet kası da dahil olmak üzere birçok insan dokusunda bulunduğu ifade edilir. ve son araştırmalar, VEGF'nin aerobik egzersize yapıldığ 1 zaman anjiyogenik tepki verdiğini göstermiştir [114]. Ahmetov ve ark. (2008). Farklı branşlardaki sporcularla yaptıkları çalışmada Sporcuların 339'nun GG genotipine, 271'nin GC genotipine, 60'nın CC genotipne sahip olduğu belirlerken, kontrol grubundan 618 kişinin GG genotipine 384 kişinin GC genotipine ve 71 kişinin CC genotipine sahip olduğunu belirlemişlerdir [115]. 


\section{Kaynaklar}

1. Koku, F.E. Sportif performansın genetik ile ilişkisi, Spor Hekimliği Dergisi. 2015, 50, 21-30.

2. Ulucan, K., (2016). Spor genetiği açısından türk sporcuların ACTN3 R577X polimorfizm literatür özeti. Clin Exp Health Sci. 2016, 6(1), 44-47.

3. Kam Kaman T, Kapıcı, S, Sercan, C, Konuk, M, Ulucan, K. Türk milli bisikletçilerde Alfa- Aktinin-3 R577X polimorfizm dağılımının belirlenmesi. Marmara Üniversitesi Spor Bilimleri Dergisi. 2017, 2(1)

4. Eroğlu, O, Zileli, R. Genetik faktörlerin sportif performansa etkisi. Uluslararası Spor Egzersiz ve Antrenman Bilimi Dergisi. 2015, 1(1), 63-76.

5. Ulucan, K, Topal, E.S, Aksulu, B.K, Yaman, B, Çiftci, İ.C, Bıyıklı, T. Atletik performans, genetik ve gen dopingi. İKSST Derg. 2015, 7(2), 58-62.

6. Sercan, C, Eken, B.F, Erel, Ş, Ülğüt, D, Kapıcı, S, Ulucan, K. Spor genetiği ve ace gen ilișkisi. İnönü Üniversitesi Beden Eğitimi ve Spor Bilimleri Dergisi. 2016, 3(2), 26-34.

7. E1der, J, Cieszczyk, P, Duniec, A.L, Maciejewska, A, Sawczuk, M, Ficek, K, Kotarska, K. Association of the 174 G/C polymorphism of the IL6 gene in polish power-orientated athletes. J Sports Med Phys Fitness. 2013, 53, 88-92.

8. Serrano, A.L, Raja, B.B, Perdiguero, E, Jardi, M, Canoves, P.M. Interleukin-6 is an essential regulator of satellite cellmediated skeletal muscle hypertrophy. Cell Metabolism. 2008, 7, 33-44.

9. Pedersen, B.K, Febbra1o, M.A. Muscle as an endocrine organ: focus on muscle-derived interleukin-6. Physiol Rev. 2008, 88, 1379-1406

10. Ruiz, J.R, Arteta, D, Buxens, A, Artieda, M, Gallego, F.G, Santiago, C, Yvert, T, Morán, M, Lucia, A. Can we identify a power-oriented polygenic profile? J Appl Physiol. 2010, 108, 561-566.

11. Zaken, S.B, Meckel, Y, Nemet, D, Kassem, E, Eliakim, A. Increased prevalence of the IL-6 -174C genetic polymorphism in long distance swimmers. Journal of Human Kinetics. 2017, 58, 121-130.

12. Cenikli, A, Nursal, A.F, Tural, E, Polat, Y, Tasmektepligil, M.Y,Yiğit, S. The Correlation Between Rs1800795 Variant of IL-6 and sports performance among turkish elite athletes. International Journal of Humanities Social Sciences and Education. 2016, 3(11), 1-5.

13. Ruiz, J.R, Buxens, A, Artieda, M, Arteta, D, Santiago, C, Romo, G.R, Lao, J.I, Gallego, F.G, Lucia, A. The -174 G/C polymorphism of the IL6 gene is associated with elite power performance. Journal of Science and Medicine in Sport. 2010, 13, 549-553.

14. Eynon, N, Ruiz, J.R, Meckel, Y, Santiago, C, Luces, C.F, Gallego, F.G, Oliveira, J, Lucia, A. İs the $-174 \mathrm{C} / \mathrm{G}$ polymorphism of the IL6 gene associated with elite power performance?, a replication study with two different caucasian cohorts. Exp Physiol 2010, 96(2), 156-162.

15. Ulucan, K, Çam, N, Sercan,C, Akbaş,B, Uyumaz, F, Yalçın, S. Genç basketbolcularda anjiotensin dönüştürücü enzim (ACE I/D) ve alfa- aktinin-3 (ACTN3 R577X) gen polimorfizmlerinin belirlenmesi için pilot bir çalışma. Hacettepe Journal of Sport Sciences. 2015, 26(3), 44-50.

16. Ulucan, K, Göle, S. ACE I/D Polymorphism determination in turkish elite wind-surfers. Sport Science Review. 2014, 1(2) 79-84.

17. Zhang, B, Tanaka, H, Shono, N, Miura, S, Kiyonaga, A, Shindo, M, Saku, K. The I allele of the angiotensin-converting enzyme gene is associated with an increased percentage of slow-twitch type 1 fibers in human skeletal muscle, Clin Genet, 2003, 63, 139-144.

18. Woods, D. R, Humphries, S. E, Montgomery, H. E. The ACE I/D polymorphism and human physical performance. Trends Endocrinol Metab. 2000, 11,416-420.

19. Costa, M.F, Slocombe, R. The use of angiotensin-1 converting enzyme I/D genetic polymorphism as a biomarker of athletic performance in humans. Biosensors. 2012, 2, 396-404.

20. Holdys, J, Krysciak, J, Stanislawski, D, Gronek, P. ACE I/D gene polymorphism in athletes of various sports disciplines. Human Movement, 2011, 12(3), 223-231.

21. Shahmoradi, S, Ahmadalipour, A, Salehi, M. Evaluation of ACE gene I/D polymorphism in ranian elite athletes. Advanced Biomedical Research. 2014, 1-10. DOI:10.4103/2277-9175.143242.

22. Ginevičienė, V, Pranculis, A, Jakaitienè, A, Milašius, K, Kučinskas, V. Genetic variation of the human ACE and ACTN3 genes and their association with functional muscle properties in lithuanian elite athletes. Medicina (Kaunas). 2011, 47(5), 284-90.

23. Ulucan, K, Sercan, C, Biyıkl1, T. Distribution of angiotensin1 converting enzyme insertion/deletion and $\alpha$-actinin- 3 codon 577 polymorphisms in turkish male soccer players. Libertas Academica. 2015, 7, 1-4.

24. Yusof, H.A, Singh, R, Zainuddin, Z, Rooney, K, Muhammed, A.M. The angiotensin I-converting enzyme I/D gene polymorphism in well-trained malaysian athletes, Sport Sci Health. 2015, 11, 187-193.

25. MacArthur, D, North, K.A. Gene for speed? the evolution and function of a-actinin-3. BioEssays. 2004, 26, 786-795.

26. Kim, H, Song, K.H, Kim, C.H. The ACTN3 R577X variant in sprint and strength performance., J. Exerc. Nutr. Biochem. 2014, 18(4), 347-353.

27. Orysiak, J, Busko, K, Michalski, R, Różycka, J.M, Gajewski, j, Lenczowska, J.M, Sitkowski, D, Pokrywka, A. Relationship between ACTN3 R577X polymorphism and maximal power output in elite polish athletes. Medicina. 2014, 50, 303-308.

28. Maffulli, N, Margiotti, K, Longo, U.G, Loppini, M, Fazio, V.M, Denaro, V. The genetics of sports injuries and athletic performance. Muscles, Ligaments and Tendons Journal 2013, 3(3), 173-189.

29. Schadock, I, Schneider, A, Silva, E.D, Buchweitz, M.R, Correa, M.N, Pesquero, J.B, Paredes, G.E.J, Araujo, R.C, Barros, C.C. Simple method to genotype the ACTN3 R577X polymorphism. Genet Test Mol Biomarkers. 2015, 19(5), 1-5.

30. Ahmetov, I, Gavrilov, D.A, Stratenkova, I, Druzhevskaya, A, Malinin, A, Romanova, E, Rogozkin, V, (2013). The association of ACE, ACTN3 and PPARA gene variants with strength phenotypes in middle school-age children. J Physiol Sci. 2013, 63(1),79-85.

31. Yang, N, Macarthur, D.G, Gulbin, J.P, Hahn, A.G, Beggs, A.H, Easteal, S, North, K. ACTN3 Genotype is associated with human elite athletic performance. Am. J. Hum. Genet. 2003, 73, 627-631.

32. Moran, C, Yang, N, Bailey, M.E.S, Tsiokanos, A, Jamurtas, A, MacArthur, D.G, North, K, Pitsiladis, Y.P, Wilson, R.H. Association analysis of the ACTN3 R577X polymorphism and complex quantitative body composition and performance phenotypes in adolescent greeks. European Journal of Human Genetics. 2007, 15, 88-93.

33. Niemi, A, Majamaa, K. Mitochondrial DNA and ACTN3 genotypes in finnish elite endurance and sprint athletes. European Journal of Human Genetics. 2005, 13, 965-969.

34. Saunders, C.J, September, A.V, Xenophontos, S.L, Cariolou, M.A, Anastassiades, L.C, Noakes, T.D, Collins, M. No association of the ACTN3 gene R577X polymorphism with endurance performance in 1ronman triathlons. Annals of Human Genetics. 2007, 71, 777-781.

35. Kıkuchı, N, Nakazato, K, Mın, S.K, Ueda, D, Igava, S. The Actn3 R577x polymorphism is associated with muscle power in male japanese athletes. Journal of Strength and Conditioning Research, 2014, 28(7),1783-1789

36. Yang, R, Shen, X, Wang, Y, Voisin, S, Ca1, G, Fu, Y, Xu, W, Eynon, N, B1shop, D.J, Yan, X. ACTN3 R577X gene variant is associated with muscle-related phenotypes in elite chinese sprint/power athletes. Journal of Strength and Conditioning Research. 2016, 31(4), 1107-1115.

37. Zarębska, A, Jastrzębski, Z, Moska, W, Duniec, A.L, Kaczmarczyk, M, Sawczuk, M, Skrendo, A.M, Ficek, K, Trybek, G, Kuklik, E.L, Semenova, E.A. Ahmetov, II., Cięszczyk, P., The AGT gene M235T polymorphism and response of power-related variables to aerobic training. Journal of Sports Science and Medicine. 2016, 15, 616-624.

38. Buxens, A, Ruiz, J.R, Arteta, D, Artieda, M, Santiago, C, Freire, M.G, Martínez, A, Tejedor, D, Lao, J.I, Gallego, F.G, 
Lucia, A. Can we predict top-level sports perfor-mance in power vs endurance events? A Genetic Approach, Scandinavian. Journal of Medicine and Science in Sports 2011,21, 570-579.

39. Gallego, F.G, Santiago, C, Freire, M.G, Yvert, T, Muniesa C.A, Serratosa, L, Altmae, S, Ruiz, J.R, Lucia, A. The C allele of the AGT Met235Thr polymorphism is associated with power sports performance, Appl. Physiol. Nutr. Metab. 2009, 34, 1108-1111.

40. Miyamoto, M.E, Murakami, H, Tsuchie, H, Takahashi, H, Ohiwa, N, Miyachi, M, Kawahara, T, Fuku, N. Lack of association between genotype score and sprint/power performance in the japanese population. Journal of Science and Medicine in Sport. 2016, 1-26. http://dx.doi.org/doi:10.1016/j.jsams.2016.06.005.

41. Zarebska, A, Sawczyn, S, Kaczmarczyk, M, Ficek, K, Karlowska, A.M, Sawczuk, M, Dunıec, A.L, E1der, J, Grenda, A, Cieszczyk, P. Association of rs699 (m235t) polymorphism in the agt gene with power but not endurance athlete status. Journal of Strength and Conditioning Research. 2013, 27(10), 2898-2903.

42. Szelid, Z, Lux, A, Kolossváry, M, Tóth, A, Vágó, H, Lendvai, Z, Kiss, L, Horvat, P.M, Bagyura, Z, Merkely, B. Righ ventricular adaptation is associated with the Glu298Asp variant of the NOS3 gene in elite athletes. PLOSONE. 2015, 1-12 DOI:10.1371/journal.pone.0141680.

43. Mcnamara, D.M, Tam, S.W, Sabolinski, M.L, Tobelmann, P, Janosko, K, Venkitachalam, L, Ofilı, E, Yancy, C, Feldman, A.M, Ghalı, J.K, Taylor, A.L, Cohn, J.N, Worcel, M.N Endothelial nitric oxide synthase (NOS3) polymorphisms in african americans with heart failure: results from the a-heft trial. Journal of Cardiac Failure. 2009, 15(3), 191-198.

44. Cenikli, A, Nursal, A.F, Tekcan, A, Demirtürk, F, Yiğit, S. The endothelial nitric oxide synthase gene variant rs2070744 in turkish elite athletes. The Annals of Eurasian Medicine 2016, 4(2), 31-34

45. Gallego, F.G, Ruiz, J.R, Buxens, A, Artieda, M, Arteta, D Santiago, C, Romo, G.R, Lao, J.I, Lucia, A. The -786 T/C polymorphism of the NOS3 gene is associated with elite performance in power sports. Eur J Appl Physiol. 2009, 107, 565-569.

46. Cięszczyk, P, Sawczuk, M, Maciejewska, A, Jascaniene, N, Eider, J. (2010). Do G894T polymorphisms of endothelial nitric oxide synthase 3 (NOS3) influence endurance phenotypes? Journal of Human Kinetics Volume 2010, $24,73-$ 80

47. Eider, J, Ficek, K, Kaczmarczyk, M, Karłowska, A.M, Sawczuk, M, Cięszczyk, P. Endothelial nitric oxide synthase g894t (rs 1799983) gene polymorphism in polish athletes. Cent. Eur. J. Biol. 2014, 9(3), 260-267.

48. Saunders, C.J, Xenophontos, S.L, Cariolou, M.A Anastassiades, L.C, Noakes, T.D, Collins, M. The bradykinin b2 receptor (BDKRB2) and endothelial nitric oxide synthase 3 (nos3) genes and endurance performance during 1ronman triathlons. Human Molecular Genetics. 2006, 15(6), 979-987.

49. Bross, S, Windelinckx, A, Mars, G.D, Huygens, W, Peeters, M.W, Aerssens, J, Vlietinck, R, Beunen, G.P, Thomis, M.A. Is ppara intron $7 \mathrm{G} / \mathrm{C}$ polymorphism associated with muscle strength characteristics in nonathletic young men? Scand J Med Sci Sports, 2011, 1-7. doi: 10.1111/j.16000838.2011.01406.x.

50. Ahmetov, I.I, Egorova, E.S, Mustafina, L.J. The ppara gene polymorphism in team sports athletes. Central European Journal of Sport Sciences and Medicine. 2013, 1(1), 19-24.

51. Ahmetov, I.I, Mozhayskaya, I.A, Flavell, D.M, Astratenkova, I.V, Komkova, A.I, Lyubaeva, E.V, Tarakin, P.P, Shenkman, B.S, Vdovina, A.B, Netreba, A.I, Popov, D.V, Vinogradova O.L, Montgomery, H.E, Rogozkin, V.A. PPARA gene variation and physical performance in russian athletes. Eur J Appl Physiol. 2006, 97, 103-108

52. Gineviciene, V, Jakaitiene, A, Tubelis, L, Kucinskas, V. Variation in the ACE, PPARGC1A and PPARA genes in lithuanian football Players. European Journal of Sport Science. 2012, 1-7. http://dx.doi.org/10.1080/17461391.2012.691117.

53. Proia, P, Bianco, A, Schiera, G, Saladino, P, Contrò, V, Caramazza, G, Traina, M
Grimaldi, K.A, Palma, A, Paoli, A. PPAR $\alpha$ gene variants as predicted performance-enhancing polymorphisms in professional italian soccer players. Journal of Sports Medicine. 2014, 5, 273-278

54. Eynon, N, Meckel, Y, Sagiv, M, Yamin, C, Amir, R, Sagiv, M, Goldhammer, E, Duarte, J.A, Oliveira, J.A. Do PPARGC1A and PPAR $\alpha$ polymorphisms influence sprint or endurance phenotypes? Scand J Med Sci Sports. 2010, 20, 145-150.

55. Tural, E, Kara, N, Agaoglu, S.A, Elbistan, M, Tasmektepligil, M.Y, Imamoglu, O. PPAR-a and PPARGC1A gene variants have strong effects on aerobic performance of turkish elite endurance athletes. Mol Biol Rep. 2014, 1-6. DOI 10.1007/s11033-014-3453-6

56. Baar, K. Involvement of PPAR ${ }^{8}$ co-activator-1, nuclear respiratory factors 1 and 2 , and PPAR $\alpha$ in the adaptive response to endurance exercise. Proceedings of the Nutrition Society. 2004, 63, 269-273.

57. Hood, D.A. Plasticity in skeletal, cardiac, and smooth muscle invited review: contractile activity-induced mitochondrial biogenesis in skeletal muscle. J Appl Physiol. 2001, 90, 1137 1157.

58. Scarpulla, R.C. Nuclear control of respiratory gene expression in mammalian cells. Journal of Cellular Biochemistry. 2006 , 97, 673-683.

59. Gopalakrishnan, L, Scarpulla, R.C. Structure, expression, and chromosomal assignment of the human gene encoding nuclear respiratory factor 1 . The Journal Of Biological Chemistry, 1995, 270, 18019-18025.

60. Kelly, D.P, Scarpulla, R.C. Transcriptional regulatory circuits controlling mitochondrial biogenesis and function. Genes Dev. 2004, 18, 357-368

61. Eynon, N, Alves, A.J, Sagiv, M, Yamin, C, Sagiv, M, Meckel, Y. Interaction between snp's in the NRF2 gene and elite endurance performance. Physiol Genomics. 2010, 41, 78-81.

62. Osburn, W.O, Kensler, T.W. Nrf 2 signaling: an adaptive response pathway for protection against environmental toxic insults. Mutation Research. 2008, 659, 31-39.

63. Bouchard, C, Rankinen, T, Chagnon, Y.C, Rice, T, Perusse, L, Gagnon, J, Borecki, I. A.P, Leon, A.S, Skinner, J.S, Wilmore, J.H, Province, M, Rao, D.C. Genomic scan for maximal oxygen uptake and its response to training in the heritage family study. J Appl Physiol. 2000, 88, 551-559.

64. He, Z, Hu, Y, Feng, L, Lu, Y, Liu, G, Xi, Y, Wen, L, Mcnaughton, L.R. NRF2 genotype improves endurance capacity in response to training. Int J Sports Med. 2007, 28, 717-721.

65. Eynon, N, Ruiz, J.R, Bishop, D.J, Santiago, C, Gallego, F.G, Lucia, A, Birk, R. The rs 12594956 polymorphism in the NRF2 gene is associated with top-level spanish athlete's performance status. Journal of Science and Medicine in Sport. 2013, 16, 135-139.

66. Eynon, N, Sagiv, M, Meckel, Y, Duarte, J.A, Alves, A.J, Yamin, C, Sagiv, M, Goldhammer, E, Oliveira, J.A. NRF2 intron $3 \mathrm{~A} / \mathrm{G}$ polymorphism is associated with endurance athletes' status. J Appl Physiol. 2009, 107, 76-79.

67. Santiago, C, Ruiz, J.R, Buxens, A, Artieda, M, Arteta, D, Freire, M.G, Romo, G.R, Altmäe, S, Lao, J.I, Gallego, F.G, Lucia, A. Trp64Arg polymorphism in ADRB3 gene is associated with elite endurance performance. Br J Sports Med. 2011, 45, 147-149.

68. Wolfarth, B, Rankinen, T, Mühlbauer, S, Scherr, J, Boulay. M.R, Pérusse, L, Rauramaa. R, Bouchard, C. Association Between a $\beta 2$-Adrenergic Receptor Polymorphism And Elite Endurance Performance. Metabolism Clinical and Experimental. 2007, 56, 1649-1651.

69. Leinewber, K. Beta adrenergic receptor polymorphism in human cardiovascular disease. Taylor \& Francis. 2004, 64-69.

70. Large, V, Hellström, L, Reynisdottir, S, Lönnqvist, F, Eriksson, P, Lannfelt, L, Arner, P. Human beta-2 adrenoceptor gene polymorphisms are highly frequent in obesity and associate with altered adipocyte beta-2 adrenoceptor function. The American Society For Clinical Investigation. 1997, 100(12), 3005-3013.

71. Nikolova, S, Yablanski, V, Vlaev, E, Stokov, L, Savov, A.S, Kremensky, I.M. Association study between 1diopathic 
scoliosis and polymorphic variants of VDR, IGF-1and AMPD1 genes. Genetics Research International. 2015, 1-6. http://dx.doi.org/10.1155/2015/852196.

72. Meckel, Y, Nemet, D, Alves, A.J, Eliakım, A, Eynon, N. The AMPD1 C34T mutation is not associated with the status of 1sraeli athletes. European Journal of Sport Science. 2012, 12(3), 244-248

73. Rubio, J.C, Martin, M.A, Rabadan, M.A, Gallego, F.G, Juan, A.F.S, Alonso, J.M, Chicharro, J.L, Perez, M, Arenas, J, Lucia, A. Frequency of the C34T mutation of the AMPD1 gene in world-class endurance athletes: does this mutation impair performance? J Appl Physiol. 2005, 98, 2108-2112.

74. Atanasov, P, Djarova, T, Kalinski, M, Petrov, L, Kaneva, R Mugandani, S, Watson, G, Jemni, M. ACTN3 and AMPD1 Polymorphism and Genotype Combinations in Bulgarian Athletes Performing Wingate Test, Journal of Sports Science. 2015,3, 1-10.

75. Cieszczyk, P, Ostanek, M, Duniec, A.L, Sawczuk, M, Maciejewska, A, Eider, J, Ficek, K, Sygit, K, Kotarska, K Distribution of the AMPD1 C34T polymorphism in polish power-oriented athletes. Journal of Sports Sciences. 2012, 30(1), 31-35

76. Ginevičienė, V, Jakaitienè, A, Pranculis, A, Milašius, K, Tubelis, L, Utkus, A. AMPD1 rs17602729 is associated with physical performance of sprint and power in elite lithuanian athletes, Bmc Genetics, 2014, 15(58), 1-9.

77. Cieszczyk, P, Eider, J, Ostanek, M, Duniec, A.L, Ficek, K, Kotarska, K, Girdauskas, G. Is the C34T polymorphism of the AMPD1 gene associated with athlete performance in Rowing? Int J Sports Med. 2011, 32, 987-991.

78. Zmijewskı, P, Grenda, A, Dunıec, A.L, Ahmetov, I, Orysıak, J, Cieszczyk, P. Effect of BDKRB2 Gene -9/+9 polymorphism on trainıng improvements in competitive swimmers. Journal of Strength and Conditioning Research 2015, 30(3), 665-671.

79. Gulliver, R, Baltic, S, Misso, N.L, Bertram, C.M, Thompson, P.J, Petrovic, M.F. Lys-des[Arg9]-bradykinin alters migration and production of interleukin-12 in monocyte-derived dendritic cells. Am J Respir Cell Mol Biol. 2011, 45, 542-549.

80. Kaplan, A.P, Joseph, K. Pathogenic mechanisms of bradykinin mediated diseases: dysregulation of an innate inflammatory pathway. Advances in Immunology. 2014, 121, 41-89.

81. Greanda, A, Leonska, D.A, Cięszczyk, P, Zmijewski, P BDKRB2 Gene $-9 /+9$ polymorphism and swimmıng performance. Biology of Sport, 2014, 31(2), 109-113.

82. Eynon, N, Meckel, Y, Alves, A.J, Nemet, D, Eliakim, A. Is there an interaction between BDKRB2 $-9 /+9$ and GNB3 $\mathrm{C} 825 \mathrm{~T}$ polymorphisms and elite athletic performance? Scand $\mathrm{J}$ Med S

ci Sports. 2011, 21, 242-246.

83. Wallımann,T, Wyss, M, Brdiczka, D, Nicolay, K, Eppenberger, H.M. Intracellular compartmentation, structure and function of creatine kinase isoenzymes in tissues with high and fluctuating energy demands: the 'phosphocreatine circuit' for cellular energy homeostasis, Biochem. J. 1992, 281, 21-40.

84. Zhou, D, Q, Hu, Y, Liu, G, Gong, L, Xi, Y, Wen, L. Musclespecific creatine kinase gene polymorphism and running economy responses to an 18-week 5000-m training programme. Br J Sports Med. 2006, 40, 988-991.

85. Yamashita, K, Yoshioka, T. Profiles of creatine kinase isoenzyme compositions in

single muscle fibres of different types, Journal of Muscle Research and Cell Motility. 1991, 12, 37-44

86. Trask, R.V, Strauss, A.V, Billadello, J.J. Developmental regulation and tissue-specific expression of the human muscle creatine kinase gene. The Journal of Biological Chemistry. 1998, 263(32), 17142-17149.

87. Fedotovskaya, O, Eider, J, Cięszczyk, P, Ahmetov, I, Moska, W, Sawczyn, S, Ficek, K, Leońska, A.D, Maciejewska, A.K, Sawczuk, M, Czubek, Z, Żychowska, M, Jascaniene, N. Association of muscle specific creatine kinase (CKM) gene polymorphism with combat athlete status in polish and russian cohorts. Science Of Martial Arts. 2013, 9(3), 233-237.

88. Eider, J, Ahmetov, I.I, Fedotovskaya, O.N, Moska, W, Cieszczyk, P, Zarebska, A, Czubek, Z, Klocek, T, Slodkowska, M.S, Karlowska, A.M, Sawczuk, M. CKM Gene
Polymorphism in Russian and Polish Rowers. Russian Journal of Genetics. 2015, 51(3), 318-321.

89. Fedotovskaya, O.N, Popov, D.V, Vinogradova, O.L, Akhmetov, I.I. Association of muscle_specific creatine kinase (CKMM) gene polymorphism with physical performance of athletes. Human Physiology. 2012, 38(1), 89-93.

90. Grenda, A, Sawczuk, M, Kaczmarczyk, M, Maciejewska, A, Umiastowska, D, Łubkowska, W, Żmijewski, P, Cięszczyk, P. Does the GNB3 C825T polymorphism influence swimming performance in competitive swimmers? Journal of Human Kinetics. 2015, 47, 99-106.

91. Klenke, S, Siffert, W. SNPs in genes encoding G proteins in pharmacogenetics.

Pharmacogenomics. 2011,12(5), 633-654

92. Gülyaşar, T, Öztürk, L, Sipahi, T, Bayraktar, B, Metin, G, Yücesir, İ, Süt, N. GNB3 gene c.825C $>$ T polymorphism and performance parameters in professional basketball players. Acta Physiologica Hungarica. 2014, 101(2), 176-184.

93. Eynon, N, Oliveira, J, Meckel, Y, Sagiv, M, Yamin, C, Sagiv, M, Amir, R, Duarte, J.A. The guanine nucleotide binding protein $\beta$ polypeptide3 gene $\mathrm{C} 825 \mathrm{~T}$ polymorphism is associated with elite endurance athletes. Exp Physiol 2009, 94(3), 344-349.

94. Faruque, M.U, Millis, R.M, Dunston, G.M, Kwagyan, J, Bond, J.V, Rotimi, C.N, Davis, T, Christie, R, Campbell, A.L. Association of GNB3 C825T polymorphism with peak oxygen consumption. Int J Sports Med. 2009, 30, 315-319.

95. Ruiz, J.R, Eynon, N, Meckel, Y, Luces, C.F, Santiago, C, Gallego, F.G, Oliveira, J, Lucia, A. GNB3 C825T Polymorphism and elite athletic status: a replication study with two ethnic groups. Int J Sports Med. 2011, 32, 151-153.

96. Sawczuk, M, Maciejewska, A.K, Cięszczyk, P, Leońska, A.D. Is GNB3 C825T polymorphism associated with elite status of polish athletes? Biol. Sport. 2014, 31, 21-25.

97. Cięszczyk, P, Eider, J, Arczewska, A, Ostanek, M, Leońska, A.D, Sawczyn, S, Ficek, K, Jascaniene, N, Kotarska, K, Sygit, K. The HIF1A gene pro582ser polymorphism in polish powerorientated athletes . Biol. Sport. 2011,28.111-114.

98. Döring, F, Onur, S, Fischer, A, Boulay, M.R, Pérusse, L, Rankinen, T, Rauramaa, R, Wolfarth, B, Bouchard, C. A common haplotype and the Pro582Ser polymorphism of the hypoxia-inducible factor- $1 \alpha$ (HIF1A) gene in elite endurance athletes. J Appl Physiol 2010, 108, 1497-1500.

99. Gabbasov, R.T, Arkhıpova, A.A, Borısova, A.V, Hakımullına A.M, Kuznetsova, A.V, Williams, A.G, Day, S.H, Ahmetov, I.I. The HIF1A gene pro582ser polymorphism in russian strength athletes. Journal of Strength and Conditioning Research. 2013, 27(8), 2055-2058.

100. Cieszczyk, P, Kalınskı, M, Ostanek, M, Jascanıene, N, Krupeck1, K, Ficek, K, Sawczuk, M, Maciejewska, A. Variation in the HIF1A gene in elite rowers. Journal of Strength and Conditioning Research. 2012, 26(12),3270-3274.

101. Zaken, S.B, Meckel, Y, Nemet, D, Eliakim, A. Can IGF-I polymorphism affect power and endurance athletic performance? Growth Horm. IGF Res. 2013, 1-4. http://dx.doi.org/10.1016/j.ghir.2013.06.005

102. Zaken, S.B, Meckel, Y, Nemet, D, Eliakim, A. IGF-I receptor $275124 \mathrm{~A}>\mathrm{C} \quad(\mathrm{rs} 1464430)$ polymorphism and athletic performance. Journal of Science and Medicine in Sport. 2014, 1-5. http://dx.doi.org/10.1016/j.jsams.2014.03.007.

103. Zaken, S.B, Malach, S, Meckel, Y, Nemet, D, Eliakim, A Frequency of the IGF A/G rs7136446 polymorphism and athletıc performance. Acta Kinesiologiae Universitatis Tartuensis. 2016, 22, 36-46.

104. Zaken, S.B, Meckel, Y, Nemet, D, Eliakim, A. High prevalence of the IGF2 rs680 GG polymorphism among toplevel sprinters and jumpers. Growth Hormone \& IGF Research. 2017, 37, 26-30.

105. Mccabe, K, Collins, C. Can genetics predict sports injury? the association of the genes GDF5, AMPD1, COL5A1 and IGF2 on soccer player injury occurrence. Sports. 2018, 6(21) 1-10.

106. Ellis, L, Collins, C, Brown, J, Pooley, W, Is AGT the new gene for muscle performance? an analysis of AGT, ACTN3, PPARA and IGF2 on athletic performance, muscle size and body fat percentage in caucasian resistance training males. Journal of Athletic 
Enhancement. 2017, 6(4), 1-6.

107. Hunter, D.J. An increase in copy number of myosin light chain kinase 1 associates with increased force production in lithuanian athletes. University of Stirling School of Sport. Research Thesis. 2014, PP16

108. Coso, J.D, Valero, M, Lara, B, Salinero, J.J, Salazar, C.G, Areces, F. Myosin light chain kinase (MLCK) gene influences exercise induced muscle damage during a competitive marathon. Plosone. 2016, 1-10. DOI:10.1371/journal.pone.0160053.

109. Clarkson, P.M, Hoffman, E.P, Zambraski, E, Dressman, H.G, Kearns, A, Hubal, M, Harmon, B, Devaney, J.M. ACTN3 and MLCK genotype associations with exertional muscle damage. J Appl Physiol. 2005, 99, 564-569.

110. Zaken, S.B, Meckel, Y, Nemet, D, Rabinovich, M, Kassem, E Eliakim, A. Frequency of the MSTN Lys(K)-153Arg(R) polymorphism among track \& field athletes and swimmers. Growth Hormone \& IGF Research. 2015, 25, 196-200.

111. Santiago, C, Ruiz, J.R, Romo, G.R, Luces, C.F, Yvert, T, Freire, M.G, Gallego, F.G, Moran, M, Lucia, A. The K153R polymorphism in the myostatin gene and muscle power phenotypes in young, non-athletic men. Plosone. 2011, 6(1), $1-6$

112. Li, X, Wang, S.J, Tan, S.C, Chew, P.Y, Liu, L, Wang, L, Wen, $\mathrm{L}, \mathrm{Ma}$, L. The A55T and K153R polymorphisms of MSTN gene are associated with the strength training-induced muscle hypertrophy among han chinese men. Journal of Sports Sciences. 2014, 32(9), 883-891.

113. Kraus, R.M, Stallings, H.W, Yeager, R.C, Gavin, T.P Circulating plasma VEGF response to exercise in sedentary and endurance-trained men. J Appl Physiol. 2004, 96, 14451450

114. Prior, S.J, Hagberg, J.M, Paton, C.M, Douglass, L.W, Brown, M.D, Mclenithan, J.C, Roth, S.M. DNA sequence variation in the promoter region of the VEGF gene impacts

VEGF gene expression and maximal oxygen consumption. Am J Physiol Heart Circ Physiol. 2006, 290, 848-855.

115. Ahmetov, I.I, Khakimullina, A.M, Popov, D.V, Missina, S.S Vinogradova, O.L, Rogozkin, V.A. Polymorphism of the vascular endothelial growth factor gene (vegf) and aerobic

http://edergi.cbu.edu.tr/ojs/index.php/cbusbed isimli yazarın CBU-SBED başlıklı eseri bu Creative Commons Alıntı-Gayriticari4.0 Uluslararası Lisansı ile lisanslanmıştır. performance in athletes. Human Physiology. 2008, 34(4), 477481 